\title{
分散型電源導入による電力貯蔵装置の 設備容量算定法に関寸る研究
}

$\begin{array}{lll}\text { 電カシステム金森 泰樹* 山村 直紀 } & \text { 石田 宗秋* } \\ & \text { *三重大学 } & \end{array}$

\section{1. はじめに}

近年, 震災の影響により系統から独立した状態でも電力 供給が可能で自然エネルギー発電システムなどの分散型電 源を主電源とした電力供給システムの需要が増加してい る。このようなシステムは変動電力の影響が大きいため, それを抑える鉛蓄電池や電気二重層キャパシタ(EDLC)など の電力貯蔵装置の設置が不可欠であり, 経済性から, それ らの設備容量を低減する必要がある。

本研究では, 独立型マイクログリッドシステムに設置さ れる電力貯蔵装置の最適容量の算定方法の確立を目指して いる。本稿では, 図 1 に示す独立型マイクログリッドを電 気回路シミュレータ上に構築し, 複数の電力貯蔵装置を使 用した場合において，それぞれの特徴を考慮した際に必要 となる容量の算定手法について検討する。

\section{2. 容量算定条件}

電力貯蔵装置の容量算定条件として，マイクログリッド システムのガスエンジン出力変動が基準值(定格の $\pm 5 \% / \mathrm{s}$ 以 内)を超えた場合，システムが不安定であるとみなし，変動 を基準值以内に抑制可能な電力貯蔵装置(鉛蓄電池と EDLC) の容量を最終的に求める算定容量とする。

電気回路シミュレータで容量算定を行う際に, 図 2 の鉛 蓄電池等価回路を使用する[1]。この回路は鉛蓄電池の出力特 性を模擬しており, 充電状態(SOC)や流れる電流の方向によ って内部抵抗や端子電圧が変化する。EDLC の等価回路に ついても作成し，容量算定を行う際に使用寸る。

\section{3. 容量算定方法と課題}

現状では，鈆蓄電池と EDLC の出力応答時間に着目して 容量算定を行う方法について検討しており，その方法につ いて説明する。図 3 より, ガスエンジン出力変動 $P_{G E}$ とリ ミッターで基準值以内に抑えた電力の差から図 4(a)の電力 貯蔵装置が補償すべき電力 $P^{*}$ comp を導出し, 4(b)の $P_{\text {comp }}^{*}$ の FFT 解析結果を得る。鉛蓄電池と EDLC の出力応答時間は それぞれ $1 \mathrm{~s}, 10 \mathrm{~ms}$ 程度であり[2]，鉛蓄電池と EDLC が補償 できる周波数帯域が異なるため, 図4(b)から, それぞれの 補償可能範囲の周波数成分を抑制する必要がある。よっ て, 補償可能範囲内の突出した周波数成分に着目して容量 算定を行うことになる。しかし，位相差により変動電力が 相殺される場合もあるため，今後はそのような問題点も考 慮した容量算定方法ついて検討していく必要がある。

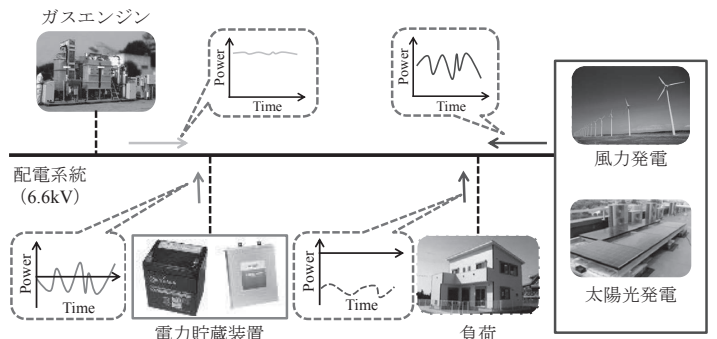

図 1 マイクログリッドシステム

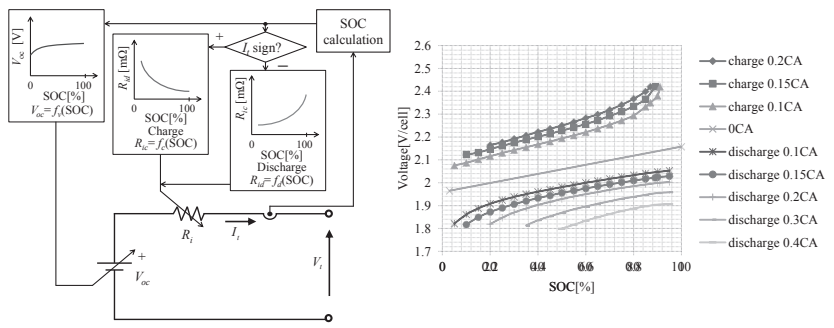

図 2 鈆蓄電池等価回路

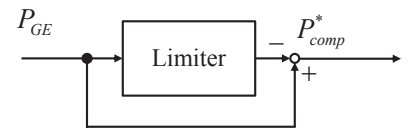

図 3 補償電力導出までのブロック図

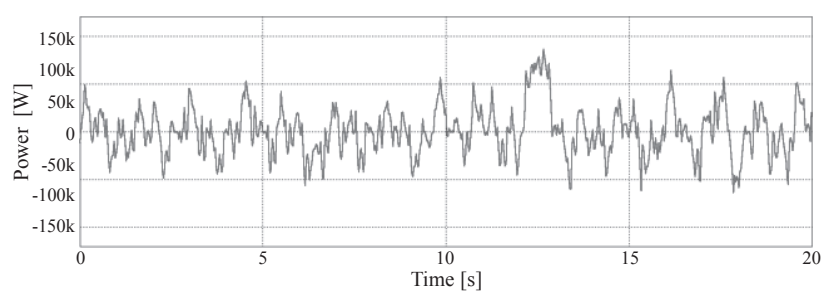

(a) 補償電力 $P^{*}$ comp

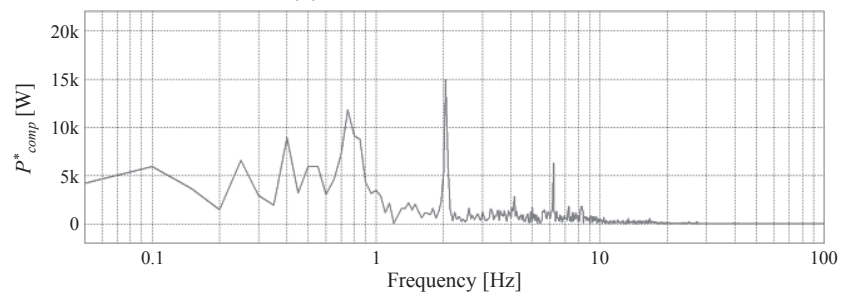

(b) FFT 解析結果

図 4 電力貯蔵装置の出力

文献

[1] Ahmed Faheem Zobaa ed., Energy Storage : Technologies and Applications (Croatia, InTech, 2013)

[2] 矢後賢次, 腰一昭 : 風力発電の系統連系システム」, 富士時報, Vol.78, No.6, 2005 